\title{
Energy content of anchovy and sardine using surrogate calorimetry methods
}

\author{
Claudia Campanini $^{1 *}{ }^{1}$, Marta Albo-Puigserver ${ }^{1,2}$, Sara Gérez ${ }^{1}$, Elena Lloret-Lloret ${ }^{1}$, Joan \\ Giménez $^{1,3}$, Maria Grazia Pennino ${ }^{4}$, Jose Maria Bellido ${ }^{5}$, Ana I. Colmenero ${ }^{1}$ and Marta Coll ${ }^{1}$ \\ ${ }^{1}$ Department of Renewable Marine Resources, Institute of Marine Sciences (ICM-CSIC), \\ Barcelona, 08003, SPAIN \\ ${ }^{2}$ Centro de Cièncias do Mar (CCMAR), Universidade do Algarve, Campus de Gambelas, Faro \\ 8005-139, PORTUGAL \\ ${ }^{3}$ MaREI Centre, Environmental Research Institute, University College Cork, Cork, P43 C573 \\ IRELAND \\ ${ }^{4}$ Fishery Department, Instituto Español de Oceanografía. Centro Oceanográfico de Vigo. Subida a \\ Radio Faro, 50-52, Vigo (Pontevedra), 36390, SPAIN \\ ${ }^{5}$ Fishery Department, Instituto Español de Oceanografía (IEO), Centro Oceanográfico de Murcia, \\ San Pedro del Pinatar, 30740, SPAIN
}

\author{
AUTHOR CONTRIBUTIONS \\ Claudia Campanini: Conceptualization, Investigation, Formal analysis, Writing - Original Draft, \\ Visualization \\ Marta Albo-Puigserver: Conceptualization, Investigation, Writing - Review \& Editing, Supervision \\ Sara Gérez: Investigation \\ Elena Lloret-Lloret: Investigation, Data curation, Writing - Review \& Editing \\ Joan Giménez: Investigation, Writing - Review \& Editing \\ Maria Grazia Pennino: Formal analysis, Writing - Review \& Editing \\ Jose Maria Bellido: Writing - Review \& Editing \\ Ana I. Colmenero: Investigation, Writing - Review \& Editing \\ Marta Coll: Conceptualization, Writing - Review \& Editing, Supervision
}

\footnotetext{
${ }^{* 1}$ Corresponding author: Claudia Campanini, +393493563106, claudiacampanini@ @otmail.it
} 


\begin{abstract}
European anchovy (Engraulis encrasicolus) and sardine (Sardina pilchardus) are crucial species for the marine ecosystem of the Northwestern Mediterranean Sea. They account for a high percentage of fish landings and they represent an important economic income. Concerns over their stock status are rising in recent years as biomass, growth, reproductive capacity and body condition of both species are declining. Therefore, there is an urgent need for a continuous and fast body condition monitoring scheme. Energy storage variability has important implications for both fish recruitment and population structure. Direct condition indices, such as bomb calorimetry, are highly reliable for measuring the energy content, but extremely time-consuming. Alternatively, fatmeter analysis and relative condition index $(\mathrm{Kn})$ have been proposed as effective indirect methods. The aim of this study is to test the application of fatmeter as a surrogate of bomb calorimetry to infer the energy content of both small pelagic fishes. For the validation, fatmeter values were compared with both energy density (ED; via bomb calorimetry) and $\mathrm{Kn}$ values. Individuals of both species were sampled monthly in Barcelona harbor for a year in order to assess seasonal variations in energy content. Our results highlight that fatmeter measurements are strongly correlated with calorimetry for sardine, while a weaker but significant correlation was found for anchovy. The observed differences between the two species are related to their breeding strategies. Based on this study, fatmeter analysis appears to be a faster and suitable method to evaluate the energy content of both species routinely., In addition, we provide a linear model to infer ED from fatmeter values of both small pelagic fish. Eventually, these findings could allow for the avoidance of bomb calorimetry and could be used to implement body condition monitoring protocols, and to boost continuous large-scale monitoring.
\end{abstract}

Key words: European anchovy, sardine, fatmeter, calorimetry, body condition.

Running title: Surrogate calorimetry methods for small pelagic fish. 


\section{Introduction}

Fish condition has been defined as a good indicator of health and physiological status of fish (Lloret et al., 2012, 2014). Although there is not a univocal definition of fish condition, it is frequently considered as a measure of individual energy storage (Gatti et al., 2018a; McPherson et al., 2011). Energy content of fish is a dynamic measure of their energy balance, which is regulated by physiological functions (i.e. growth, maintenance or reproduction) and environmental factors (i.e. temperature and food availability) (Albo-Puigserver et al., 2017). As a result, energy content of fish species has also been used to track changes in the ecosystem and as proxy of environmental status, especially of species that play a pivotal role for the functioning of the ecosystem such as small pelagic fish (Nikolsky et al., 2012; Shulman et al., 2005).

Since energy content influences growth rate, reproduction success and mortality rate, the assessment of body condition combined with other variables (e.g. biomass, exploitation, abundance) is useful to monitor the state of fish stocks and to predict future changes in terms of abundance and productivity (Lambert and Dutil, 1997; Lloret et al., 2012). Moreover, energy condition indices such as energy density (ED) are needed to build bioenergetic models (Gatti et al., 2017), which allow the quantification of energy allocation and can be applied in physiology, ecology, aquaculture, and fisheries management (Deslauriers et al., 2017).

In order to evaluate fish condition, direct and indirect methods are currently used (Schloesser and Fabrizio, 2017; Lloret et al., 2014). Direct indices, such as ED from direct calorimetry or lipid content, provide a precise measure of energy storage that can be used as an estimation of fitness (Lloret et al., 2014), but are highly time-consuming and not suitable for a continuous monitoring. By contrast, indirect indices, which can be based on length-mass relationship (length-based indices), organ mass (i.e. organosomatic indices), or tissue properties (e.g. fatmeter) (Schloesser and Fabrizio, 2017), allow a rapid assessment of fish condition. However, prior to their use as an indirect proxy of energy storage, they should be validated investigating their relationship with direct condition indexes (Davidson and Marshall, 2010; McPherson et al., 2011; Schulte-Hostedde et al., 
2005).

When evaluating the variability in body condition, other parameters, such as size, life stage (reproductive/resting period) and season need to be taken into consideration (Brosset et al 2015, Gatti et al., 2018). Indeed, energy content is strongly affected by temporal changes in food availability and this in turns impacts life-history strategy (Albo-Puigserver et al., submitted; Lloret et al., 2014). This is the case of European anchovy Engraulis encrasicolus (Linnaeus, 1758) and sardine (also named European pilchard) Sardina pilchardus (Walbaum, 1792), which display different energy allocation and life-history strategies. European anchovy (hereinafter anchovy) is an income breeder that allocates energy directly to reproduction, which occurs in spring and summer; conversely, sardine is a capital breeder that stores energy during the resting period prior to the reproduction in autumn and winter (Albo-Puigserver et al., 2017; Costalago and Palomera, 2014; Ganias et al., 2007; McBride et al., 2015; Palomera et al., 2007).

Sardine and anchovy stocks in the western Mediterranean Sea are currently highly fished or overexploited (Coll and Bellido, 2019; FAO, 2018; GFCM, 2019). In the last decades, a decrease in body condition has been observed for both species in several parts of the Mediterranean Sea, with a concurrent drop in landings, abundance, growth and age structure (Albo-Puigserver et al. submitted, Brosset et al., 2017; Coll and Bellido, 2019; Van Beveren et al., 2014). Due to their importance in biomass in mid-trophic positions, sardine and anchovy are key elements of the marine food web having an essential role in the energy transfer from lower to upper trophic levels (Coll et al., 2008, 2006; Cury et al., 2000, 2011; Piroddi et al., 2015). Thus, a decline in fish condition can have a bottom-up effect on top-predators populations negatively impacting their breeding success and fitness (Crawford et al., 2006; Österblom et al., 2008; Piroddi et al., 2017).

In order to evaluate the body condition of sardine and anchovy, morphometric indices, such as Le Cren relative condition index $(\mathrm{Kn})$, have been widely used (Brosset et al., 2015b; Van Beveren et al., 2014). This index rely on the assumption that any deviation from the weight-length relationship standard can be assumed as an indication of the relative fitness of the individual (Lloret et al., 
2014). Being low-cost, quick, and usually non-disruptive, these morphometric indices are used in many fields. Although their use have been validated for sardine and anchovy (Albo-Puigserver et al., 2020; Brosset et al., 2015a; Gatti et al., 2018a; McPherson et al., 2011), their utilization to infer energy content is still controversial (Davidson and Marshall, 2010; McPherson et al., 2011; Sardenne et al., 2016; Stevenson and Woods Jr, 2006).

On the other hand, direct measures of energy density using bomb calorimetry, defined as the energy content per weight unit $\left(\mathrm{kJ} \cdot \mathrm{g}^{-1}\right)$, have demonstrated to be a precise measure of fish bioenergetics condition (Albo-Puigserver et al., 2020, 2017; Gatti et al., 2018a; Tirelli et al., 2006). The benefit of bomb calorimetry is that it gives information on the average energy of the proximate composition of fish (weighted average of protein, lipid and carbohydrates energy densities) (Gatti et al., 2018a). Unfortunately, a continuous monitoring of body condition with this technique is impractical as it is time-consuming, costly, and impossible to carry in-situ (i.e. monitoring in harbors or in oceanographic campaigns).

The use of fish fatmeter has many advantages as the measurement is rapid, repeatable, accurate, non-destructive, and the device is portable, making it very convenient for field research. Fish store energy mainly as lipids and thus they drive most of the variation of energy density measurements (Anthony et al., 2000; Rosa et al., 2010; Spitz et al., 2010). Numerous studies described a positive correlation between fatmeter and lipid content or morphometric condition indices (Bayse et al., 2018; Brosset et al., 2015a; Davidson and Marshall, 2010; Másílko et al., 2016). Furthermore the accuracy of fatmeter as a surrogate of direct techniques to estimate energy reserves has been assessed for several species (Bayse et al., 2018; Goñi and Arrizabalaga, 2010; Mann et al., 2009; Mesa and Rose, 2015; Schloesser and Fabrizio, 2017). As for the sardine and anchovy, the use of Distell Fish Fatmeter has been validated as a good indirect method to estimate lipid content (Brosset et al., 2015a), but whether it could also provide accurate estimates of energy content has not been investigated. Therefore, the main objective of this study was to assess the suitability of fish fatmeter as surrogate of bomb calorimetry to estimate energy density and therefore fish condition of anchovy 
and sardine from the Northwestern Mediterranean Sea, considering temporal and ontogenetic changes in body condition. Furthermore, we compared fatmeter measurements with Le Cren relative condition index, as this latter index has already been validated for both species as a surrogate for energy content (Brosset et al., 2015a). Secondly, where the correlation between fatmeter values (expressed in lipid percentage) and energy density (ED; expressed in $\mathrm{kJ} \cdot \mathrm{g}^{-1}$ ) turned out to be strong, a model fitted to this relationship was provided, as such model could be used to infer ED from fatmeter values allowing a faster body condition assessment protocol for sardine and anchovy in the future. Moreover, the inferred ED values could be used to measure the transfer of energy between compartments and ultimately for bioenergetic (Gatti et al., 2017; Pecquerie et al., 2009) and ecosystem models.

\section{Material and methods}

\subsection{Study area and sampling}

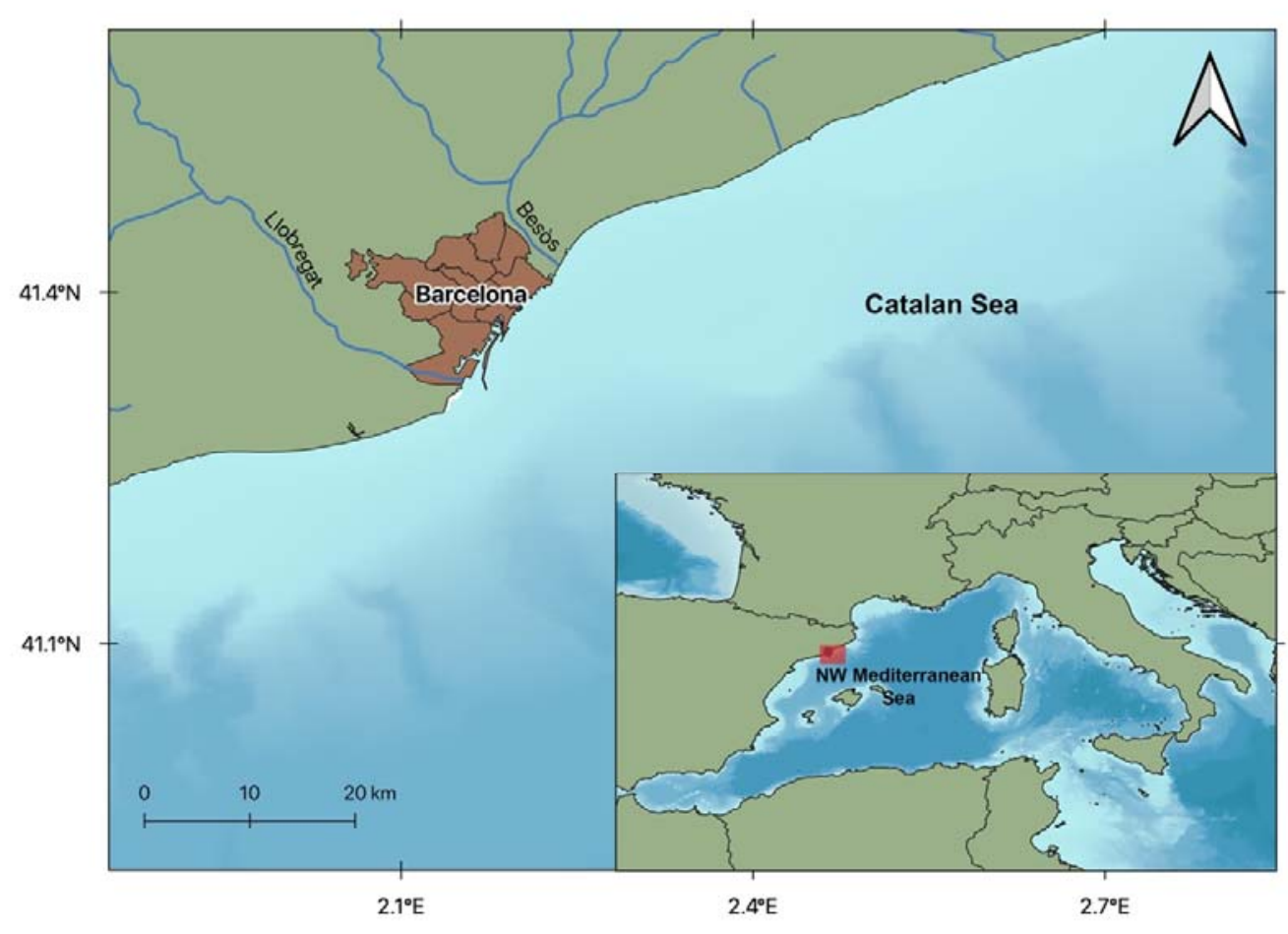

Figure 1. Study area corresponding to the coast of Barcelona where samples were collected. 
The present study was carried off Barcelona harbor in the Catalan Sea, Northwestern Mediterranean Sea (Figure 1). Overall, the Catalan coast presents a relatively narrow continental shelf (Martín et al., 2008). The hydrography of this coastal area is highly influenced by anthropogenic factors due to the proximity of the city and its high urban density (Romero et al., 2014). Salinity increases moving towards the edge of the continental shelf due to the high freshwater discharge of both natural and anthropogenic origin in the area (Guillén et al., 2019). Indeed, freshwater inputs include not only discharge from the Besòs River to the north and the Llobregat River to the south, but also from many storm sewers (Figure 1). Such inputs consist mainly of treated waters, however even untreated waters are released to the sea during heavy rainfall (Arin et al., 2013). In temperate oceanic zones, such as this area, primary production displays significant interannual changes (Bosc et al., 2004; Estrada, 1996). The observed peaks in phytoplankton biomass (main peak in winterspring and secondary peak in autumn) can be explained by both increased freshwater discharges, related to higher precipitations, and vertical mixing due to decreased temperatures and strong winds. Conversely, primary production reaches its minimum during summer due to the scarcity of nutrients caused by water stratification (Arin et al., 2013).

Samples for both species were obtained monthly, from July 2018 to June 2019, from commercial purse-seiners landings off the Barcelona harbor. Data of anchovy from November and December 2019 are missing due to lack of catch (November) and anchovy annual fishing closure (December). For all the statistical analyses, seasons were defined as follows: summer from July to September, autumn from October to December, winter from January to March, and spring from April to June. In order to capture length variability, 40 individuals covering all available targeted size-ranges were sampled for each species per month. Size $(\mathrm{cm})$, weight $(\mathrm{g})$, sex (female, male and indeterminate), and fatmeter measurements (explained later in more detail) were recorded for each individual.

Ten individuals belonging to different size ranges from each month were randomly selected for calorimeter analysis in order to obtain ED values from all the size-spectrum. 
Table 1. Sample size by month and species for each index: Kn, fatmeter (Fatm) and energy density (ED). Minimum (min) and maximum (max) monthly values of body length $(\mathrm{cm})$ during 2018-2019.

\begin{tabular}{|c|c|c|c|c|c|c|c|c|c|}
\hline \multirow[b]{2}{*}{ Year } & \multirow[b]{2}{*}{ Month } & \multicolumn{4}{|c|}{ Anchovy } & \multicolumn{4}{|c|}{ Sardine } \\
\hline & & $\begin{array}{c}\text { Body length } \\
(\mathrm{cm}) \\
(\min -\mathrm{max})\end{array}$ & $\mathrm{Kn}$ & Fatm & ED & $\begin{array}{c}\text { Body length } \\
(\mathrm{cm}) \\
(\min -\max )\end{array}$ & $\mathrm{Kn}$ & Fatm & ED \\
\hline \multirow{6}{*}{2018} & July & 11.40-16.00 & 40 & 40 & 10 & $14.20-18.50$ & 38 & 40 & 10 \\
\hline & August & $9.00-15.20$ & 40 & 40 & 10 & $9.40-18.30$ & 40 & 40 & 10 \\
\hline & September & $9.10-15.10$ & 40 & 40 & 10 & $13.70-18.20$ & 40 & 40 & 10 \\
\hline & October & $8.30-16.10$ & 40 & 40 & 10 & $13.20-18.60$ & 40 & 40 & 10 \\
\hline & November & - & - & - & - & $10.20-16.40$ & 40 & 40 & 10 \\
\hline & December & - & - & - & - & $11.90-17.60$ & 40 & 40 & 10 \\
\hline \multirow{6}{*}{2019} & January & $12.00-15.70$ & 40 & 35 & 10 & $12.00-18.20$ & 40 & 40 & 10 \\
\hline & February & $10.30-15.30$ & 40 & 40 & 10 & $9.90-18.30$ & 40 & 40 & 10 \\
\hline & March & $12.70-15.20$ & 40 & 40 & 10 & $12.30-16.20$ & 40 & 40 & 10 \\
\hline & April & $10.50-15.00$ & 40 & 40 & 9 & $13.20-16.80$ & 40 & 40 & 10 \\
\hline & May & $10.60-14.50$ & 40 & 40 & 10 & $12.50-16.10$ & 40 & 40 & 10 \\
\hline & June & $11.30-15.00$ & 40 & 40 & 10 & $12.50-16.20$ & 40 & 40 & 10 \\
\hline
\end{tabular}

\subsection{Fatmeter analyses}

The Fish fatmeter works exploiting the transmission of low-power microwaves to measure the dielectric properties and thus the water content of the tissue beneath the skin (Kent, 1990). We used an FFM-992 Distell Fatmeter, the so-called "Small Head Model", to process the fatmeter samples, as the $3 \mathrm{~cm}$-long sensor is more suitable for small-sized fish. Prior to the utilization, the instrument was calibrated using the standard calibration provided by the manufacturer, i.e. ANCHOVY-2 and SARDINE-2. Two measures were taken for each side of the fish placing the microstrip sensor along the lateral line, as recommended in the user manual (Distell, 2010). Finally, mean fatmeter values were calculated from the 4 measurements recorded for each specimen ( 2 for each side) (Brosset et al., 2015a). Some anchovy shorter than $10.3 \mathrm{~cm}$ were too small and the Fish Fatmeter could not record any measurement, so two individuals placed side by side were jointly measured and the same fatmeter value was recorded. 


\subsection{Energy density analyses}

A total of 120 and 100 calorimetric analyses were performed for sardine and anchovy, respectively. Samples for direct calorimetry analysis were prepared following the protocol described by AlboPuigserver et al. (2017) except for the oven temperature that was $60{ }^{\circ} \mathrm{C}$.

ED was estimated as the heat release from the combustion of a small subsample and it was measured using Parr 6725 Semimicro Oxygen Bomb Calorimeter. The instrument was previously calibrated combusting benzoic acid according to the Operating Instruction Manual (Parr Instrument Company, 2012). Two 50-150 mg pellets per specimen were combusted in the calorimeter. In the eventuality that the two measurements differed by more than $5 \%$, a third pellet from the same individual was analyzed. Values, expressed in calories per gram (cal.g $\left.{ }^{-1}\right)$ of dry weight (DW), were converted to kilojoules per gram of wet weight $\left(\mathrm{kJ} \cdot \mathrm{g}^{-1} \mathrm{WW}\right)$. The conversion to a wet weight (WW) basis was achieved by multiplying mean ED values $\left(\mathrm{kJ} \cdot \mathrm{g}^{-1} \mathrm{DW}\right)$ by dry weight proportion (dry weight proportion $=$ dry weight $\cdot$ wet weight $^{-1}$ ). Finally, mean ED of each individual was calculated from the subsamples' measurements (Albo-Puigserver et al., 2017).

\subsection{Relative condition index $(\mathrm{Kn})$}

The relative condition index $(\mathrm{Kn})$ was determined for each individual as the ratio of its total weight (TW) to the predicted weight (PW) for a fish of the same total length (Le Cren, 1951).

The predicted weight (PW) was computed using the weight-length regression expressed by the following equation: $\mathrm{PW}=\mathrm{a} \cdot \mathrm{TL}^{\mathrm{b}}(\mathrm{TL}=$ Total Length $)$.

The weight-length relationship is species- and population-specific and thus it was computed ad hoc for this study. The two coefficients, $a$ and $b$, where estimated for the two species taking into account all the individuals from the sampling period (anchovies: $a=0.0036, b=3.216$; sardines: $a$ $=0.0031, \mathrm{~b}=3.334)$.

\subsection{Statistical analyses}


We explored the relationship of fatmeter values and ED with size (fish total length, in $\mathrm{cm}$ ), using Generalized Additive Models (GAM). GAMs were run with the function gam included in R library mgcv (Wood, 2011) using restricted maximum likelihood (REML) for smoothing parameter estimation, while the R library visreg (Breheny and Burchett, 2017) was used for GAMs visualization. A Gaussian distribution with an identity link was used to fit condition indices. Since condition indices are influenced by many biological and environmental variables, GAMs were fitted for each species considering also sex and season and their concurrent effects. In particular, season and sex were included in GAMs as factors, while size was treated as a continuous variable. Finally, as the rest of the variability could be due to some individual intrinsic aspects, we also added a random individual effect, hereafter defined as ID. In order to avoid overfitting, degrees of freedom were restricted to 6 for both main effects and interactions.

GAMs by species were selected as the best-to-fit model based on the explained deviance and the Akaike Information Criterion (AIC) (Burnham and Anderson, 2002).

We also generated linear regression and log-log regression models of fatmeter values against DW. Furthermore, the relationship between DW and ED in wet weight basis $\left(\mathrm{kJ} \cdot \mathrm{g}^{-1} \mathrm{ww}\right)$ described by Hartman and Brandt (1995) was investigated for each species as to compare our results with previous literature, i.e. Gatti et al., (2018) for both species in the Bay of Biscay and the English Channel, Albo-Puigserver et al. (2020; unpub. data) for both species in Tarragona coast and Tirelli et al. (2006) for anchovy in the Adriatic Sea. In particular, linear regression and log-log regression models were performed for each species between DW and ED. Then, results of the mentioned published studies were plotted against our results for visual comparison and the estimated regression parameters were analytically compared with the Welch-test. In addition, the relationships between percentage of DW and ED in dry weight basis $\left(\mathrm{kJ} \cdot \mathrm{g}^{-1} \mathrm{dw}\right)$ for both species were plotted and are included in the Supplementary materials (Figure S1).

In order to assess the correlation and therefore the eventual interchangeability between indices, pairwise Spearman's rank non-parametric correlation test was performed between Kn, fatmeter 
values and ED. We expected a large year-round variation in condition indices related to the reproduction investment; therefore, we split the original dataset according to the estimated reproductive and resting period for both species, the former lasting from October to March for sardine and from April to September for anchovy.

Finally, as we hypothesized that fatmeter values could allow indirect estimation of energy density, linear regression and log-log regression models were also performed to assess the relationship between fatmeter and ED for both species. Prior to fit the models, the presence of outliers was checked through the Bonferroni Outlier Test and they were eventually excluded.

For the present study, all the statistical analyses were performed with $\mathrm{R}$ version 3.6.1 (R Core Team, 2019) and a p-value threshold of 5\% was considered as significance level.

\section{Results}

\subsection{Monthly variation in indirect and direct condition indices}

Overall, sardine exhibited a higher seasonality in condition indices compared to anchovy, but in both species the lowest values of $\mathrm{Kn}$, fatmeter and $\mathrm{ED}$ were found from November to February 2018-2019 (Figure 2). As for sardine, the percentage of lipid estimated by fatmeter measurements changed markedly throughout the year (Figure 2A). The highest mean values were recorded in July $(18.00 \pm 1.64$ lipid \%) and followed by a slow decrease from August to October. Lipid percentage drastically declined in November and reached its minimum average value in December. A slow recovery was registered in late winter while from March onwards it surpassed the $10 \%$.

Regarding anchovy, the lipid percentage as measured with fatmeter was more stable, with mean values ranging from 5 to $10 \%$ all year round, apart from March when the mean value was higher (11.4+1.85 lipid \%). 

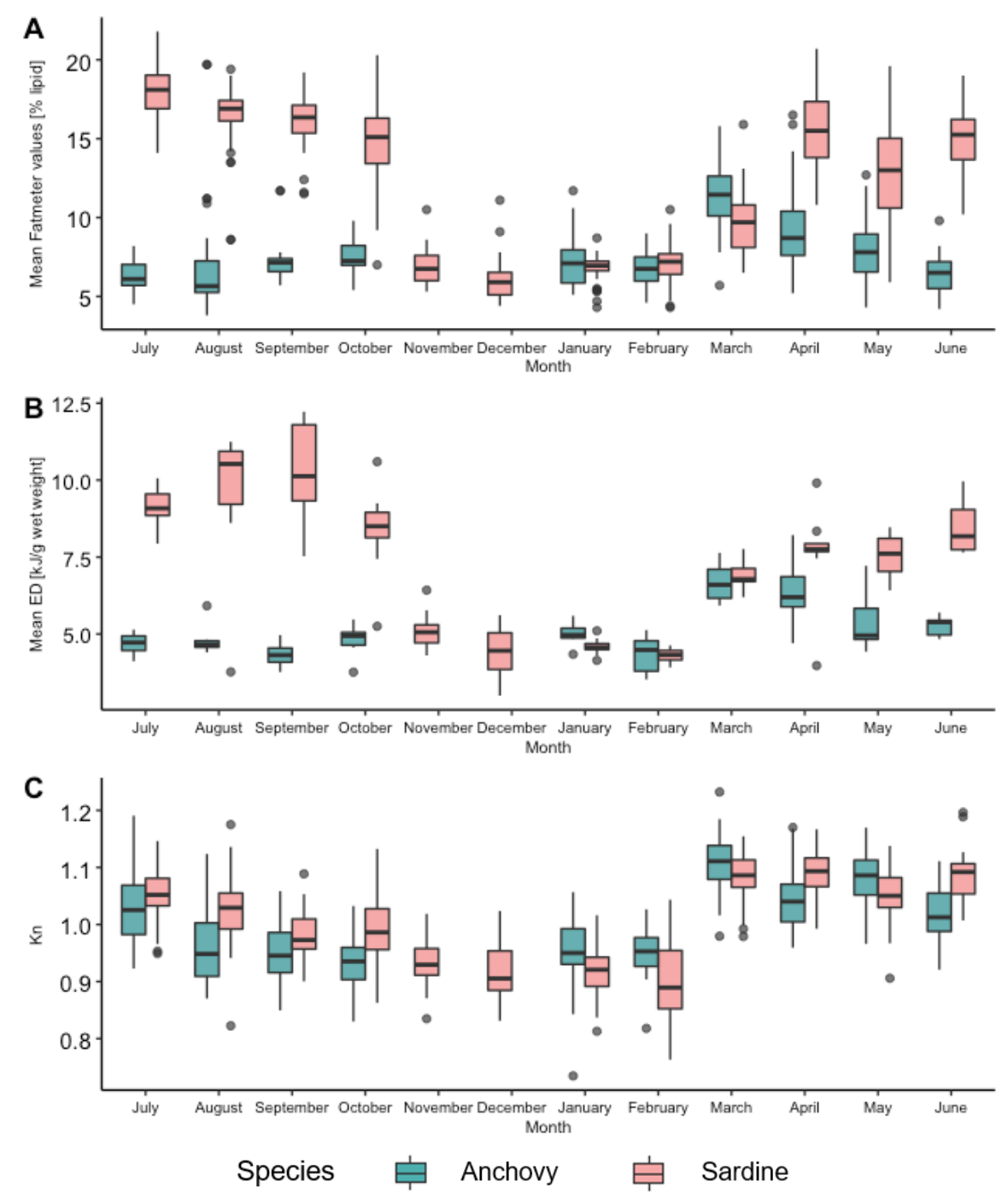

Figure 2. Boxplot of monthly variation of the three condition indices: A) Fatmeter, B) Energy density (ED), and C) Relative body condition (Kn), for anchovy (in dark cyan) and sardine (in coral rose) from July 2018 to June 2019. Boxplots hinges represent the $1^{\text {st }}$ and $3^{\text {rd }}$ quartiles. Horizontal lines represent the medians.

Months with relatively high ED seemed to have higher intra-monthly variability for both anchovy and sardine. Sardine ED was very high in late summer, reaching its peak in September, then started to fall from October and progressively rise again in March. Year-round ED pattern for anchovy was similar to its fatmeter pattern. Mean ED values oscillated around $5 \mathrm{~kJ} \cdot \mathrm{g}^{-1}$ until February with an increase between March and May, while they ranged from 5 to $7.5 \mathrm{~kJ} \cdot \mathrm{g}^{-1}$ during the rest of the year (Figure 2B).

Concerning Kn values for sardine, we observed a gradual decrease from July to February (February, 


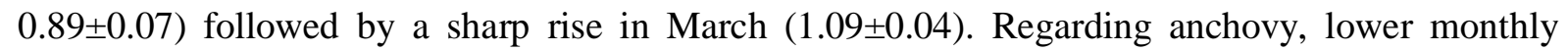
variation in Kn was observed and, similar to sardine, they displayed a substantial increase in March (Figure 2C).

\subsection{Variation in energy content with length, sex, and season}
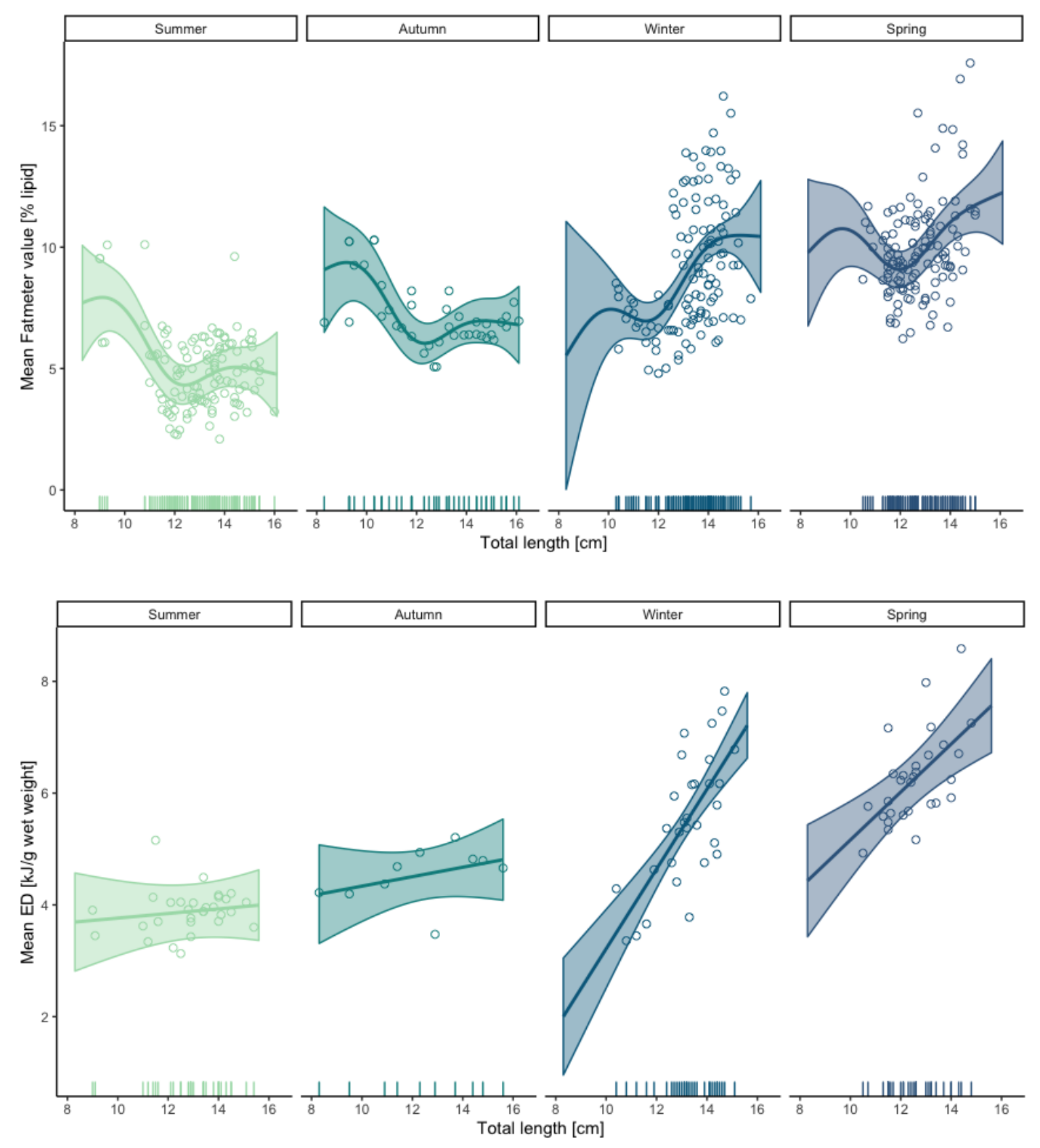

Figure 3. Partial effect plots of season on predicted fatmeter (top) and ED (bottom) values by the GAMs against total length for anchovy. Seasonal model fit with average predictions (continuous lines) and the $95 \%$ confidence intervals. 
For anchovy, the deviance explained by GAMs models fitted to the evolution of ED and fatmeter values with size (Figure 3) was $34.3 \%$ for fatmeter values and $52.7 \%$ for ED. Regarding fatmeter GAMs, all the effects proved to be significant (Table S2). However, the interaction between sex and season was not included in the model as its effect was only significant for females and males in winter and its inclusion did not substantially improve the explained deviance. Fatmeter GAMs by season were quite wiggly at visualization (Figure 3). Indeed, fatmeter values tended to increase with size in winter and spring but this trend was reversed in summer and autumn, as higher values were recorded for small-sized individuals. By contrast, the relationships found with models fitted to ED by season were linear and we excluded both sex and the interaction between sex and season from the model as they were not significant. ED GAM showed a rather slight increase in summer and autumn values in response to an increase in size, while they displayed a steeper linear slope in winter and spring. The lack of specimens shorter than $10 \mathrm{~cm}$ and longer than $15 \mathrm{~cm}$ during winter and spring explained the large confident interval in both ED and fatmeter models. Finally, the random individual effect was statistically relevant for both ED and fatmeter models. 

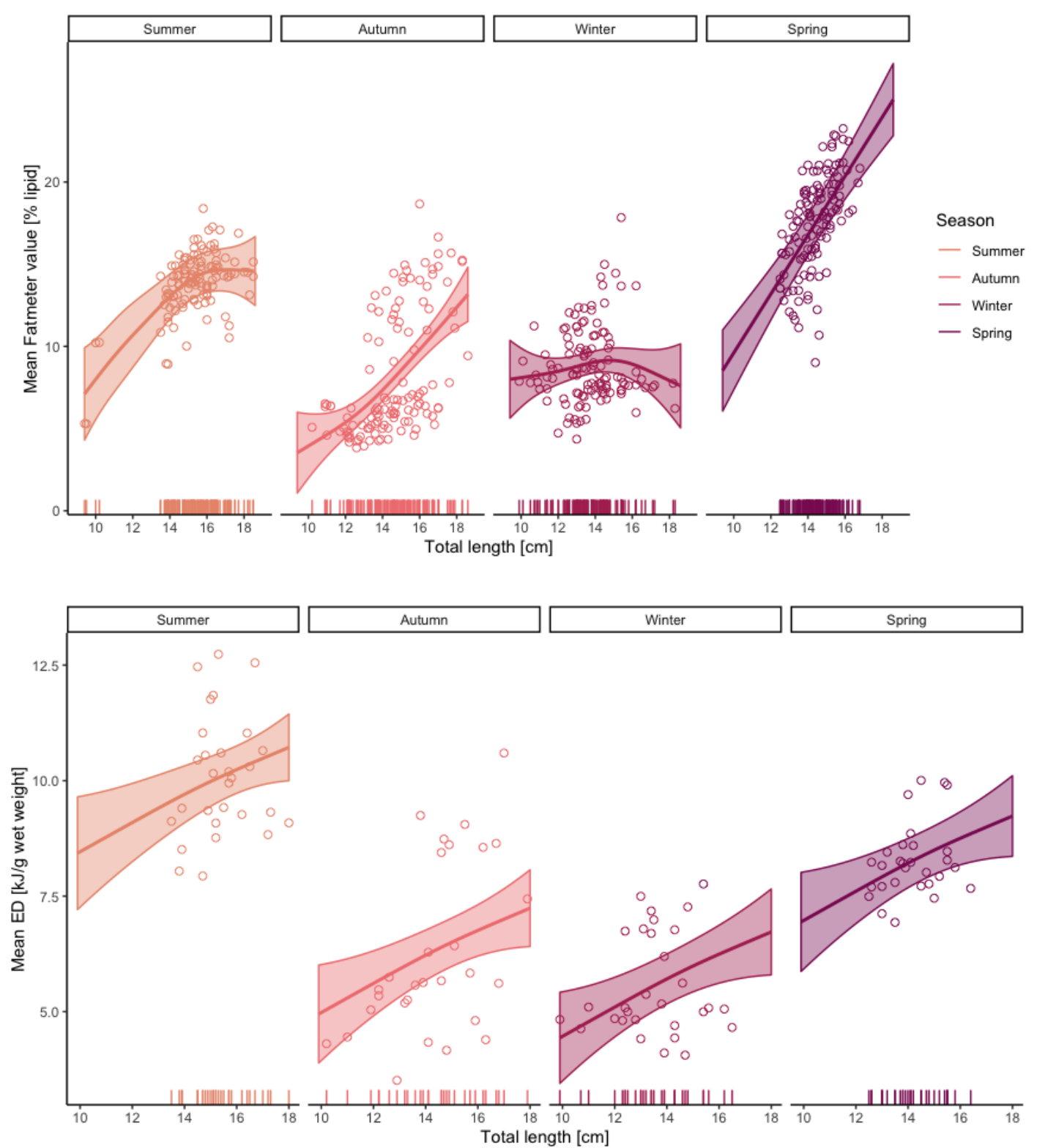

Figure 4. Partial effect plots of season on predicted fatmeter (top) and ED (bottom) values by the GAMs against total length for sardine. Seasonal model fit with average predictions (continuous lines) and the $95 \%$ confidence intervals.

With regards to sardine, GAM fitted to the variability of fatmeter against total length, season, and sex explained $74.1 \%$ of the deviance, while the one fitted to ED explained the $69.2 \%$ (Table S3 and Figure 4). In accordance with the principle of parsimony, we excluded sex and its interaction with season from fatmeter model as their effects were not relevant, but for female-male difference in winter. Conversely, difference between sexes proved to be significant and therefore it was included in ED GAM. Notably, fatmeter values and size were not always positively related in all seasons; 
indeed, for summer and winter, increasing fatmeter values were estimated until a total length of 16 $\mathrm{cm}$, while over this length the estimated fatmeter values tended to gradually decrease (Figure 4). ED GAMs showed that ED values increased with fish length during all the seasons with an almost linear trend. For both ED and fatmeter models in summer and spring, the large confidence intervals estimated for short individuals were consequent of the low number of specimen shorter than $13 \mathrm{~cm}$ collected during these seasons. The smoothed random individual effect exerted a significant influence only in fatmeter values variation.

Overall, GAMs fitted both to fatmeter and ED have rather high residual standard deviations for both anchovy (fatmeter GAM: RSD $\approx 1.9$; ED GAM: RSD $\approx 0.75$ ) and sardine (fatmeter GAM: RSD $\approx$ 2.5; ED GAM: RSD $\approx 1.30)$.

\subsection{Fatmeter validation}

Linear regression and log-log models showed that an increase in dry weight (DW) corresponded to an increase in both fatmeter values and energy density (ED) for both species, thus they were positively correlated (Figures 5).

With respect to fatmeter-DW relationship (Table 2), linear and log-log models displayed a strong fit for sardine ( $\mathrm{R}^{2}$ of 0.88 and 0.85 for linear and log-log models, respectively), while a rather scarce fit was observed for anchovy ( $\mathrm{R}^{2}$ values 0.35 and 0.28 for linear and log-log models, respectively) (Figure 5A-B).

Conversely, the ED-DW models exhibited a very strong fit for both species being $\mathrm{R}^{2}$ values from 0.76 to 0.80 for anchovy and $0.92-0.93$ for sardine (Figure 5C-D). Moreover, sardine models showed a slightly steeper slope, therefore the same rise in DW meant a higher increment in ED for sardine than for anchovy. 

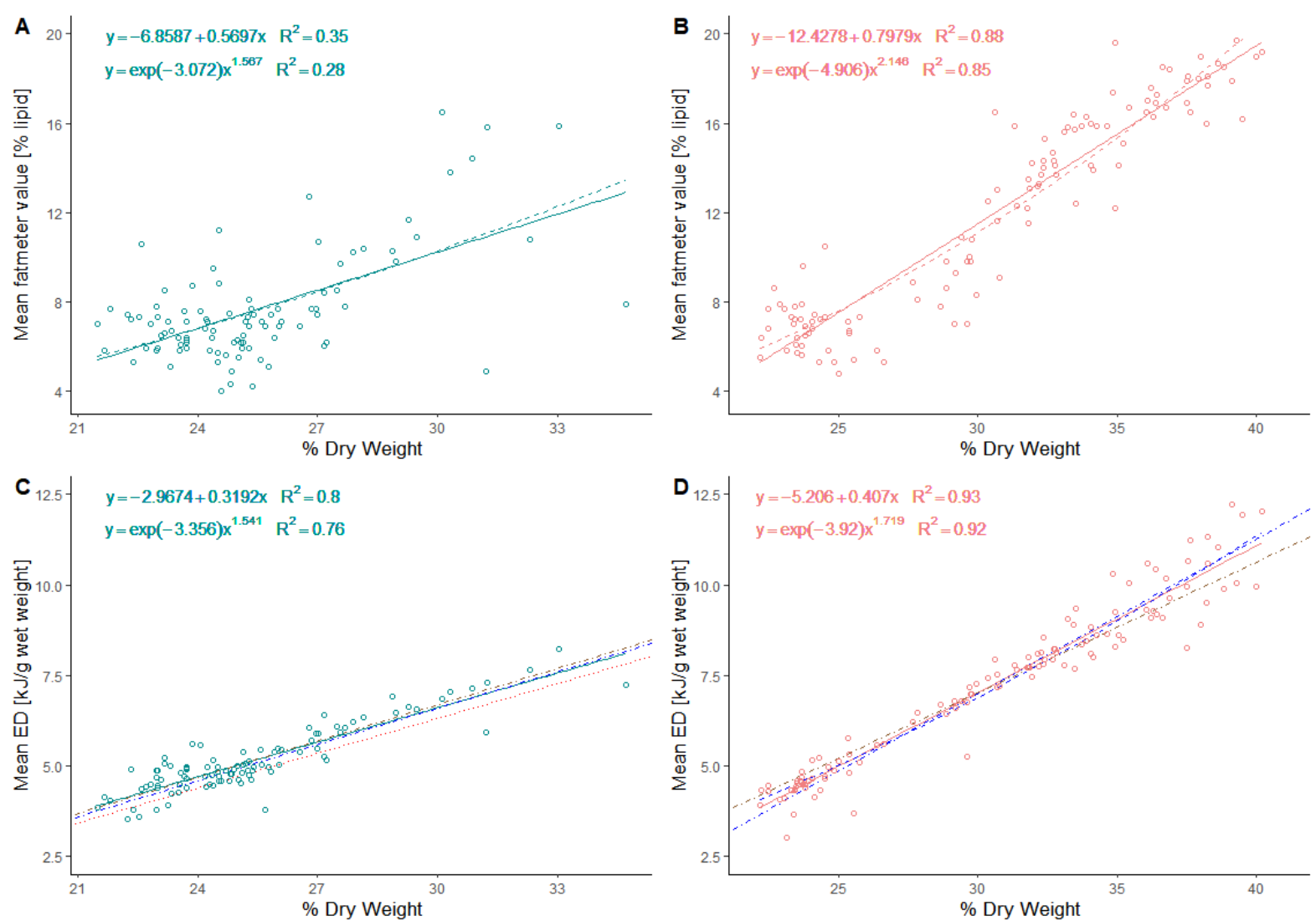

Figure 5. A) Fatmeter values (\% lipid) against dry weight ( $g$ ) of anchovy: linear model (solid line), log-log model (dashed line). B) Fatmeter values (\% lipid) against dry weight (g) of sardine: linear model (solid line), log-log model (dashed line). C) Energy density in wet weight basis (kJ/g wet weight) against dry weight (g) of anchovy: linear model (cyan solid line) with equation, log-log model (cyan solid line) with equation, Gatti's linear model (blue dot-dash line), Gatti's log-log model (blue dashed line), Tirelli's linear model (red dotted line) and Albo linear model (brown dot-dash line). D) Energy density in wet weight basis ( $\mathrm{kJ} / \mathrm{g}$ wet weight) against dry weight (g) of sardine: linear model (pink solid line) with equation, log-log model (pink dashed line) with equation, Gatti's linear model (blue dot-dash line), Gatti's log-log model (blue dashed line) and Albo linear model (brown dot-dash line).

Table 2. Coefficients of both linear and log-log regression models between fatmeter values (\% lipid) and dry weight $(\%)$.

\begin{tabular}{|c|c|c|c|c|c|}
\hline Fatmeter $v s$ DW & Species & $\mathrm{R}^{2}$ & Coefficient & Estimate & Std. error \\
\hline \multirow{3}{*}{ Linear model } & \multirow{2}{*}{ Anchovy } & \multirow{2}{*}{0.351} & Intercept & -6.859 & 1.994 \\
& & & Slope & 0.570 & 0.078 \\
\cline { 2 - 6 } & \multirow{2}{*}{ Sardine } & \multirow{2}{*}{0.796} & Intercept & -10.571 & 1.060 \\
& & & Slope & 0.741 & 0.034 \\
\hline \multirow{3}{*}{ Log-log model } & \multirow{2}{*}{ Anchovy } & \multirow{2}{*}{0.282} & Intercept & -3.073 & 0.810 \\
& & & Slope & 1.567 & 0.251 \\
\cline { 2 - 6 } & \multirow{2}{*}{ Sardine } & \multirow{2}{*}{0.849} & Intercept & -4.906 & 0.283 \\
& & & Slope & 2.146 & 0.083 \\
\hline
\end{tabular}

All the pair-wise Spearman correlations between condition indices were significantly positive 
$(\mathrm{p}<0.05)$ for anchovy. Such correlations were stronger in the resting period compared to the reproductive period (Figure 6 A-C).
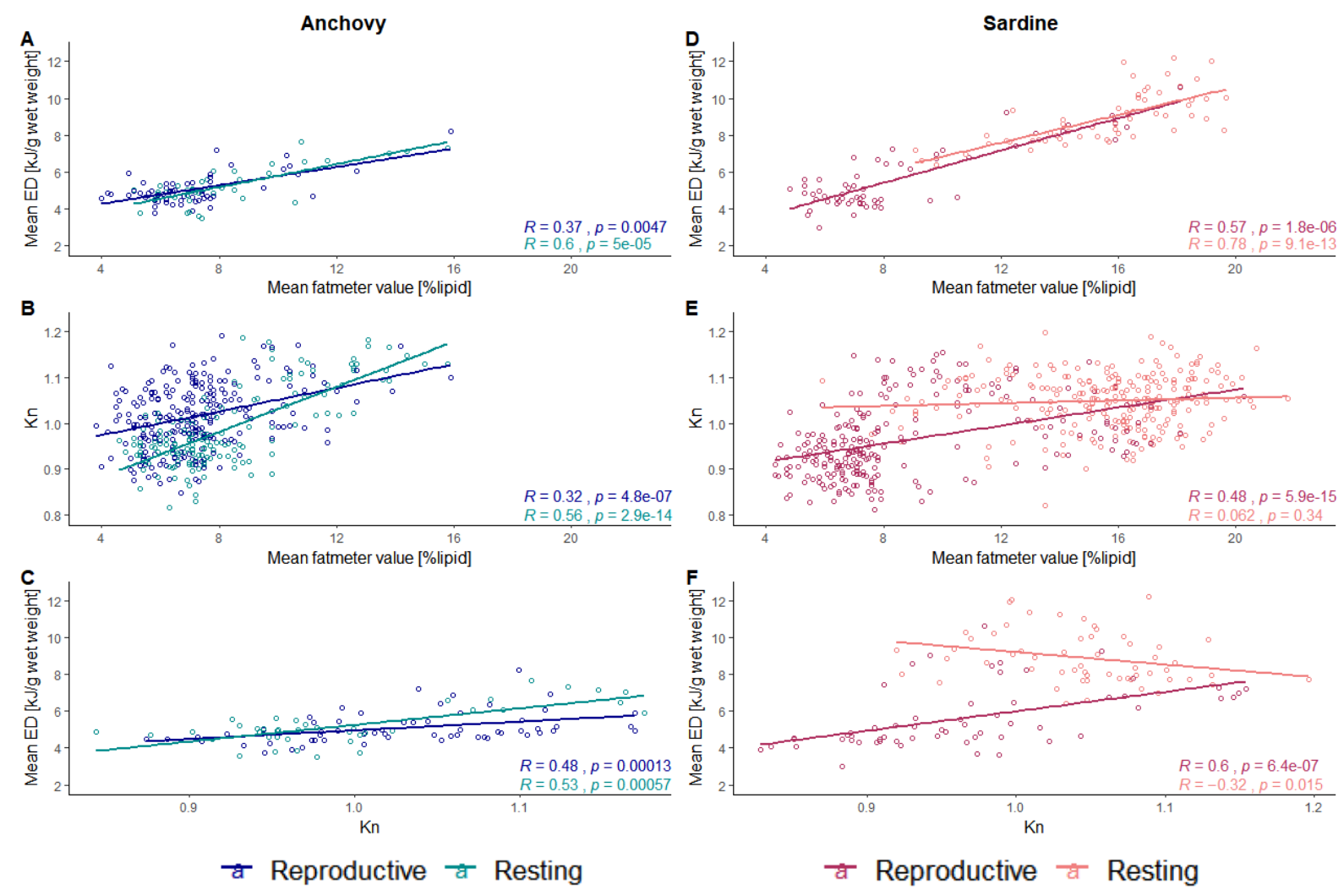

Figure 6. Spearman correlation tests between each of the condition indices for anchovy (A-C) and sardine (D-F) during the resting and reproductive period.

According to the Spearman correlation test, there was a significant relationship between every condition index in both resting and reproductive period for sardine (p-value < 0.05), except for Kn and fatmeter during the resting period $(\mathrm{p}=0.34)$ (Figure $6 \mathrm{D}-\mathrm{F})$. As opposed to the other pair-wise tests, $\mathrm{Kn}$ and $\mathrm{ED}$ of sardine during resting period exhibited a negative correlation $(\mathrm{R}=-0.32)$. With respect to the other comparisons, a stronger correlation was observed between fatmeter and ED in both periods. 

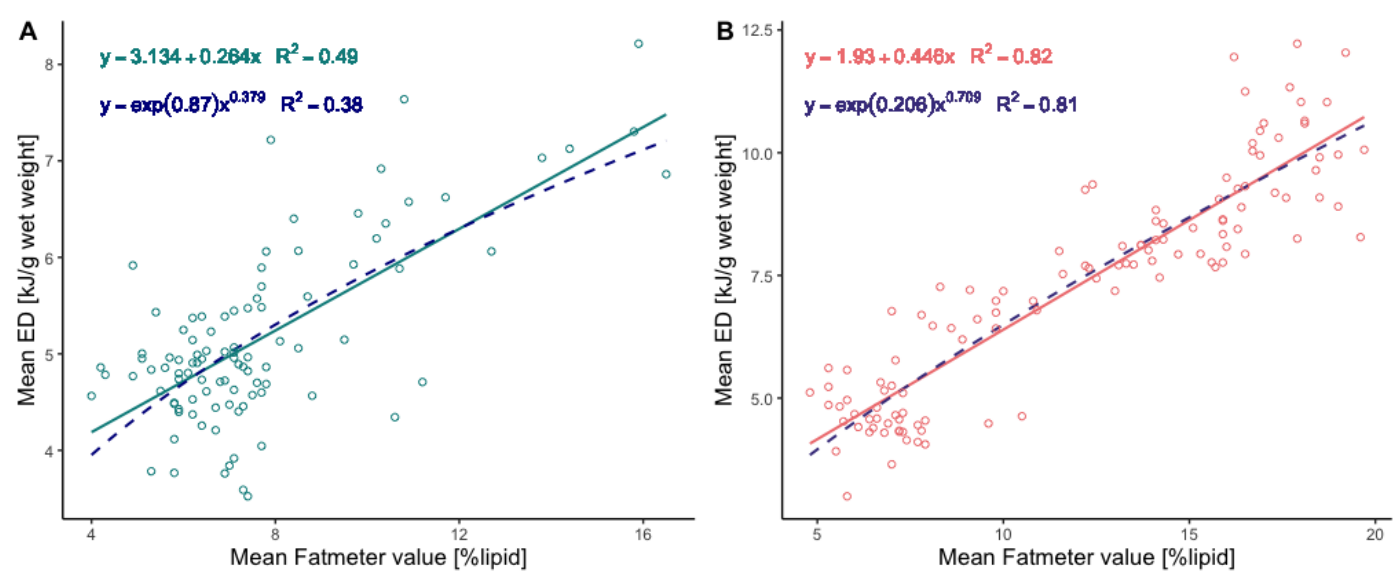

Figure 7. Energy density in wet weight basis (kJ/g ww) against mean fatmeter values (\% lipid) of A) anchovy and B) sardine. Linear model (solid line), log-log model (dashed line).

Anchovy's linear regression model between fatmeter values and ED exhibited a significantly better fit $\left(\mathrm{R}^{2}=0.49\right)$ than the $\log -\log$ model $\left(\mathrm{R}^{2}=0.38\right)$ (Figure $\left.7 \mathrm{~A}\right)$. Linear model describing the relationship between mean fatmeter values and mean ED for sardine provided a slightly better fit $\left(\mathrm{R}^{2}=0.82\right)$ than the log-log model $\left(\mathrm{R}^{2}=0.81\right)($ Figure $7 \mathrm{~B})$.

\section{Discussion}

The key aim of this study was to assess the suitability of fish fatmeter as a surrogate of bomb calorimetry for sardine and anchovy. Since our results have revealed that fatmeter and bomb calorimetry measurements are highly correlated for both species, fatmeter can be used to estimate the energy content of sardine and anchovy in the Northwestern Mediterranean Sea.

\subsection{Monthly variation in indirect and direct condition indices}

Tracking monthly variation in energy content can help in predicting the response of small pelagic fish to environmental changes (Albo-Puigserver et al., 2020), thus choosing the condition index that better reflects the actual energy content is crucial.

Consistently with previous body condition assessments of anchovy and sardine from the southern

Catalan coast (Albo-Puigserver et al., 2020, 2017), our results showed that year-round variation in hodv condition indices was more nronounced for sardine than for anchovv. This intersnecies 
difference in body condition seasonal patterns reflects their distinct life-history strategies. Indeed sardine behaves as capital breeder (Albo-Puigserver et al., 2020, 2017; Brosset et al., 2015b; Ganias et al., 2007; Nunes et al., 2011), accumulating energy storage during the resting period when high fatmeter and ED values were recorded. While ED values of sardine had been increasing during summer, fatmeter values started to slowly decrease as lipids are generally the first macromolecule to be catabolized for energy in fishes (Shulman and Love, 1999; Tocher, 2003). Then the significant drop in all, indirect and direct, indices recorded from November to February represents the overall weight loss and lipid depletion in muscle, compensating for the energy invested for gonad development (Brosset et al., 2015b).

Interestingly, the high lipid \% and ED values recorded for sardine in summer and at the beginning of autumn, with ED values close to $10 \mathrm{~kJ} \cdot \mathrm{g}^{-1} \mathrm{ww}$, contrasted with the lower values previously reported in the southern Catalan coast in 2012 (maximum ED values close to $7 \mathrm{~kJ} \cdot \mathrm{g}^{-1} \mathrm{ww}$; AlboPuigserver et al., 2020). Low body condition and energy reserves of sardine, before the reproduction period, have been related to unfavorable environmental conditions and changes in primary and secondary production (Brosset et al 2015b; Albo-Puigserver et al., 2020). Therefore, the high energy content of sardine observed in the present study may result from better environmental conditions that could have contributed to a higher reproduction success (Garrido et al., 2007). However, further analysis combining condition indices and environmental variables should be performed to investigate this further.

On the other hand, the beginning of anchovy reproductive period is coupled with the late-winter peak in phytoplankton biomass and to the subsequent rise in zooplankton abundance (Palomera et al., 2007). As such, energy investment for reproduction could be partially counterbalanced by food intake thanks to the high prey availability (Basilone et al., 2006; Estrada, 1996). This explain the lower values and the less marked variation in energy content observed for anchovy in comparison with sardine and illustrates the income breeder behavior observed for this species. 


\subsection{Variation in energy content with length, sex, and season}

In this study, the evolution of fatmeter values and ED with size displayed different seasonal patterns between sardine and anchovy. With respect to anchovy, high fatmeter values were recorded for some small individuals. This could be due to the fact that smaller individuals were measured in couple; thus, the related fatmeter values may be hindered and represent incorrect measurements of the lipid content. As far as sardine are concerned, the low fatmeter values recorded for large-class individuals in summer and winter may derive from a spawning period starting earlier and lasting longer, as previously observed by Nunes (2011). As there is not much literature on fatmeter values variation with length, we encourage future research to cover this aspect.

Despite previous studies analyzing ED variation with size reported that their relationship was not always linear (Pedersen and Hislop, 2001; Tirelli et al., 2006), here, anchovy and sardine ED-size models exhibited a positive linear fit with increasing length. These results contrast with the decrease in ED observed for larger anchovy individuals in Gatti et al. (2018) and Tirelli et al. (2006). However, it should be considered that in this study, only few individuals belonging to the larger size-classes (> $15 \mathrm{~cm}$ ) were sampled, whereas in Gatti et al. (2018) larger individuals reached 18 and $25 \mathrm{~cm}$ for anchovy and sardine, respectively. This is also true for sardine as Gatti et al. (2018) reported a drop in ED for individuals over $19 \mathrm{~cm}$, however our sample did not include fish longer than $18 \mathrm{~cm}$. The paucity of larger-class individuals have already been attested for sardine populations from the NW Mediterranean (Albo-Puigserver et al., submitted; Pennino et al., 2020b, 2020a; Saraux et al., 2019; Van Beveren et al., 2014) and the Bay of Biscay (Véron et al., 2020).

While the season factor significantly affected both condition indices for both species, the effect of sex was limited and therefore not included in most models. Indeed, for anchovy, sex had a significant influence on fatmeter values, but not on ED. Conversely, sardine fatmeter values did not vary between males and females, in accordance with previous observation on muscle lipid content by Garrido et al. (2008). However, when relevant, the impact of sex for both species could be traced mainly to the presence of immature individuals (indeterminates); instead, differences in sex among 
adult individuals, i.e. males and females, was significant only in winter for both sardine and anchovy.

\subsection{Validating fatmeter as surrogate of energy density}

Even though the accuracy and repeatability of fatmeter analysis for sardine and anchovy has already been assessed (Brosset et al., 2015a), this study presents the validation of fatmeter analysis as a proxy of bomb calorimetry. The relationship between fatmeter and DW was investigated for both species using both linear and log-log models. Fatmeter-DW models can be used to obtain an estimation of lipid content not only in body condition assessments for ecological purposes, but also for fish meal production and human consumption (Albrecht-Ruiz and Salas-Maldonado, 2015; Marin et al., 2010; Šimat and Bogdanović, 2012; Tufan et al., 2011; Zlatanos and Laskaridis, 2007). Anchovy displayed a stronger relationship between ED and DW than between fatmeter and DW, whereas for sardine both regressions results were strong. In any case, ED and DW were highly correlated for both species $\left(\mathrm{R}^{2}>0.75\right)$. Although Gatti et al. (2018) suggested that ED-DW models are species- and area-specific, ED-DW models from this study were similar to the ones fitted to populations from different geographical areas (Table S4), i.e. the Bay of Biscay and the English Channel (Gatti et al., 2018), Tarragona (Albo-Puigserver et al., 2020; unpub. data) and the Adriatic Sea (Tirelli et al., 2006). Nevertheless, Welch's test results (Table S5) revealed that the coefficient estimates from our study were significantly different to the ones from previous literature except for the slope of anchovy's linear model from Tirelli et al. (2006). However, the statistical difference may not reflect an actual ecological difference as overall the regression lines were very similar. A previous study suggested the use of ED-DW log-log models, instead of linear models, as they may better account for ontogenetic variability (Gatti et al., 2018a). Despite this, in our study, linear models provided a slightly better fit than log-log models for both species and this may be explained by the clear prevalence of adults, who were presumably mature, and the absence of early juveniles in our samples. 
According to Spearman's correlation test, positive strong correlations were observed between fatmeter and ED. Furthermore, the results highlighted differences in all the pairwise-correlations between condition indices depending on the reproductive state of the fish as previously observed by Brosset et al. (2015). Indeed, fatmeter and ED for anchovy and sardine clearly showed higher correlation during the resting period, when the lipid content is higher, compared to the reproductive period. Neither sardine's ED nor fatmeter values were significantly correlated with Kn during the resting period. Therefore, future body condition assessments for this species should consider that Kn may not be a proper condition index during non-reproductive period, as it may not reflect the energetic status.

ED-fatmeter linear regression models provided a weaker fit for anchovy than for sardine. The stronger ED-fatmeter relationship for sardine may be traceable to its higher energy reserves, consisting mainly of lipids, which are the main driver of ED variability (Albo-Puigserver et al., 2020; Rosa et al., 2010). In contrast, anchovy variation in ED is probably prompted by changes in other macromolecules, i.e. proteins, which cannot be measured with fatmeter analysis (AlboPuigserver et al., 2020). Indeed, while direct calorimetry estimates the energy density of the whole proximate composition (i.e. lipids, proteins, and carbohydrates), fatmeter gives an indirect measure only of the lipid content.

Previous study by Brosset et al. (2015) validated the use of fatmeter comparing its lipid estimations with the ones by thin-layer chromatography with Iatroscan MK-VI. In contrast with our results, the relationship between lipid content estimations by means of fatmeter and chromatography was stronger for anchovy than for sardine. This weaker relationship for sardine may be attributable to the fact that chromatography analysis were performed only on gonad and muscle tissue, without considering mesenteric fat, while fatmeter measurements were taken on the whole fish. Indeed mesenteric fat is a long-term storage site for sardine (Lloret et al., 2014) and it tends to increase from spring to summer in concomitance with the rise in zooplankton abundance in the study area (Albo-Puigserver et al., 2017). Furthermore, a previous study on Atlantic herring, Clupea harengus, 
evidenced a strong correlation between fatmeter measurements and mesenteric fat (McPherson et al., 2011).

Overall, the relative ability of fatmeter values to estimate energy content proved to be significantly higher for sardine. This outcome can be traced to the smaller size of anchovy that increases the difficulty and reduces the repeatability of fatmeter measurements (Brosset et al., 2015a).

The interchangeability of the two techniques, fatmeter and calorimetry analysis, may lead to an implementation of fatmeter measurements in the body condition assessment protocol. Indeed, EDfatmeter models could provide adequate estimates of energy density in field applications of bioenergetics models.

\section{Conclusions}

Our study supports the use of fatmeter analysis as a surrogate of bomb calorimetry to infer the energy density of both sardine and anchovy. Thanks to the fatmeter validation provided in this study, future bioenergetic assessments of these two species could benefit from this technique as it allows rapid energy content estimation and can be carried out in situ. In turn, this would shorten the time required for large-scale and continuous monitoring that contribute to the understanding of population dynamics and to fish stock management and conservation (Rosa et al., 2010). Moreover, as opposed to Kn values, which are population-specific (Lloret et al., 2014), fatmeter values may be compared among populations from different geographical areas.

However, our results confirm that the validation of body condition indices should consider the ontogenetic variation (Schloesser and Fabrizio, 2017; Wuenschel et al., 2006), the reproductive state (Brosset et al., 2015b; Nunes et al., 2011) and the seasonality. Indeed, fatmeter correlation with ED was demonstrated to be stronger for sardine than for anchovy and it changed depending on

the reproductive period. Similarly, fatmeter values and dry weight displayed stronger relationship for sardine. Therefore, fatmeter analysis could conceivably be a better proxy of energy content for species that store high quantity of fat such as sardine; nevertheless, its use proved to be appropriate 
also for anchovy, in particular during the resting period and for larger individuals.

Finally, using the species-specific equations provided in this study, fatmeter values could be transformed into ED units and eventually serve as inputs for bioenergetics models.

\section{Acknowledgments}

This work was supported by PELWEB [ES-PN-2017-CTM2017-88939-R] project. C.C. was funded by an Erasmus+ Mobility for Traineeships scholarship. We would like to thank the Cofraria de Pescadores de Barcelona for their help in the acquisition of the samples.

\section{References}

Albo-Puigserver, M., Muñoz, A., Navarro, J., Coll, M., Pethybridge, H., Sánchez, S., Palomera, I., 2017. Ecological energetics of forage fish from the Mediterranean Sea: seasonal dynamics and interspecific differences. Deep Sea Research Part II: Topical Studies in Oceanography $140,74-82$.

Albo-Puigserver, M., Pennino, M., Bellido, J., Colmenero, A., Giraldez, A., Hidalgo, M., Steenbeek, J., Torres, G., Coll, M., submitted. Changes in life history traits of small pelagic fish in the western Mediterranean Sea. Frontiers in Marine Science.

Albo-Puigserver, M., Sánchez, S., Coll, M., Bernal, M., Sáez-Liante, R., Navarro, J., Palomera, I., 2020. Year-round energy dynamics of sardine and anchovy in the north-western Mediterranean Sea. Marine Environmental Research 105021. https://doi.org/10.1016/j.marenvres.2020.105021

Albrecht-Ruiz, M., Salas-Maldonado, A., 2015. Chemical Composition of Light and Dark Muscle of Peruvian Anchovy (Engraulis ringens) and Its Seasonal Variation. Journal of Aquatic Food Product Technology 24, 191-196. https://doi.org/10.1080/10498850.2012.762705

Anthony, J.A., Roby, D.D., Turco, K.R., 2000. Lipid content and energy density of forage fishes from the northern Gulf of Alaska. Journal of Experimental Marine Biology and Ecology 248, 53-78. https://doi.org/10.1016/S0022-0981(00)00159-3

Arin, L., Guillén, J., Segura-Noguera, M., Estrada, M., 2013. Open sea hydrographic forcing of nutrient and phytoplankton dynamics in a Mediterranean coastal ecosystem. Estuarine, Coastal and Shelf Science 133, 116-128.

Basilone, G., Guisande, C., Patti, B., Mazzola, S., Cuttitta, A., Bonanno, A., Vergara, A.R., Maneiro, I., 2006. Effect of habitat conditions on reproduction of the European anchovy (Engraulis encrasicolus) in the Strait of Sicily. Fisheries Oceanogr 15, 271-280. https://doi.org/10.1111/j.1365-2419.2005.00391.x

Bayse, S.M., Regish, A.M., McCormick, S.D., 2018. Proximate composition, lipid utilization and validation of a non $\square$ lethal method to determine lipid content in migrating American shad Alosa sapidissima. Journal of Fish Biology 92, 1832-1848. https://doi.org/10.1111/jfb.13624

Bosc, E., Bricaud, A., Antoine, D., 2004. Seasonal and interannual variability in algal biomass and primary production in the Mediterranean Sea, as derived from 4 years of SeaWiFS observations. Global Biogeochemical Cycles 18. https://doi.org/10.1029/2003GB002034

Breheny, P., Burchett, W., 2017. Visualization of regression models using visreg. The R Journal 9, 
$56-71$.

Brosset, P., Fromentin, J.-M., Ménard, F., Pernet, F., Bourdeix, J.-H., Bigot, J.-L., Van Beveren, E., Pérez Roda, M.A., Choy, S., Saraux, C., 2015a. Measurement and analysis of small pelagic fish condition: A suitable method for rapid evaluation in the field. Journal of Experimental Marine Biology and Ecology 462, 90-97. https://doi.org/10.1016/j.jembe.2014.10.016

Brosset, P., Fromentin, J.-M., Van Beveren, E., Lloret, J., Marques, V., Basilone, G., Bonanno, A., Carpi, P., Donato, F., Keč, V.Č., 2017. Spatio-temporal patterns and environmental controls of small pelagic fish body condition from contrasted Mediterranean areas. Progress in oceanography 151, 149-162.

Brosset, P., Ménard, F., Fromentin, J.-M., Bonhommeau, S., Ulses, C., Bourdeix, J.-H., Bigot, J.-L., Van Beveren, E., Roos, D., Saraux, C., 2015b. Influence of environmental variability and age on the body condition of small pelagic fish in the Gulf of Lions. Marine Ecology Progress Series 529, 219-231.

Burnham, K.P., Anderson, D.R., 2002. Model selection and multimodel inference: A practical information-theoretic approach, 2nd ed. Springer, New York. Model selection and multimodel inference, 2nd ed. Springer, New York 2.

Coll, M., Bellido, J., 2019. Evaluation of the population status and specific management alternatives for the small pelagic fish stocks in the Northwestern Mediterranean (SPELMED)Final Report SC NR 02-TENDER EASME. EMFF/2016/32-SPELMED: 85.

Coll, M., Palomera, I., Tudela, S., Dowd, M., 2008. Food-web dynamics in the South Catalan Sea ecosystem (NW Mediterranean) for 1978-2003. Ecological Modelling 217, 95-116. https://doi.org/10.1016/j.ecolmodel.2008.06.013

Coll, M., Palomera, I., Tudela, S., Sardà, F., 2006. Trophic flows, ecosystem structure and fishing impacts in the South Catalan Sea, Northwestern Mediterranean. Journal of Marine Systems 59, 63-96.

Costalago, D., Palomera, I., 2014. Feeding of European pilchard (Sardina pilchardus) in the northwestern Mediterranean: from late larvae to adults. Scientia Marina 78, 41-54.

Crawford, R.J.M. j, Barham, P.J., Underhill, L.G., Shannon, L.J., Coetzee, J.C., Dyer, B.M., Leshoro, T.M., Upfold, L., 2006. The influence of food availability on breeding success of African penguins Spheniscus demersus at Robben Island, South Africa. Biological Conservation 132, 119-125. https://doi.org/10.1016/j.biocon.2006.03.019

Cury, P., Bakun, A., Crawford, R.J.M., Jarre, A., Quiñones, R.A., Shannon, L.J., Verheye, H.M., 2000. Small pelagics in upwelling systems: patterns of interaction and structural changes in "wasp-waist" ecosystems. ICES Journal of Marine Science 57, 603-618. https://doi.org/10.1006/jmsc.2000.0712

Cury, P.M., Boyd, I.L., Bonhommeau, S., Anker-Nilssen, T., Crawford, R.J.M., Furness, R.W., Mills, J.A., Murphy, E.J., Österblom, H., Paleczny, M., Piatt, J.F., Roux, J.-P., Shannon, L., Sydeman, W.J., 2011. Global Seabird Response to Forage Fish Depletion-One-Third for the Birds. Science 334, 1703. https://doi.org/10.1126/science.1212928

Davidson, D., Marshall, C.T., 2010. Are morphometric indices accurate indicators of stored energy in herring Clupea harengus? Journal of Fish Biology 76, 913-929. https://doi.org/10.1111/j.1095-8649.2010.02546.x

Deslauriers, D., Chipps, S.R., Breck, J.E., Rice, J.A., Madenjian, C.P., 2017. Fish Bioenergetics 4.0: An R-Based Modeling Application. Fisheries 42, 586-596. https://doi.org/10.1080/03632415.2017.1377558

Distell, 2010. User manual, Distell Fish Fatmeter Model FFM-992 and Model FFM-692. Distell, West Lothian, Scotland.

Estrada, M., 1996. Primary production in the northwestern Mediterranean. Producción primaria en el Mediterráneo noroccidental.

FAO, 2018. The State of Mediterranean and Black Sea Fisheries. General Fisheries Commission for the Mediterranean, Rome. 
Ganias, K., Somarakis, S., Koutsikopoulos, C., Machias, A., 2007. Factors affecting the spawning period of sardine in two highly oligotrophic Seas. Marine Biology 151, 1559-1569. https://doi.org/10.1007/s00227-006-0601-0

Garrido, S., Rosa, R., Ben-Hamadou, R., Cunha, M.E., Chícharo, M.A., van der Lingen, C.D., 2008. Spatio-temporal variability in fatty acid trophic biomarkers in stomach contents and muscle of Iberian sardine (Sardina pilchardus) and its relationship with spawning. Marine Biology 154, 1053-1065.

Gatti, P., Cominassi, L., Duhamel, E., Grellier, P., Le Delliou, H., Le Mestre, S., Petitgas, P., Rabiller, M., Spitz, J., Huret, M., 2018a. Bioenergetic condition of anchovy and sardine in the Bay of Biscay and English Channel. Progress in Oceanography 166, 129-138. https://doi.org/10.1016/j.pocean.2017.12.006

Gatti, P., Cominassi, L., Duhamel, E., Grellier, P., Le Delliou, H., Le Mestre, S., Rabiller, M., Spitz, J., Huret, M., 2018b. Bioenergetic condition of anchovy and sardine in the Bay of Biscay and English Channel. Progress in Oceanography 166, 129-138. https://doi.org/10.1016/J.POCEAN.2017.12.006

Gatti, P., Petitgas, P., Huret, M., 2017. Comparing biological traits of anchovy and sardine in the Bay of Biscay: A modelling approach with the Dynamic Energy Budget. Ecological Modelling 348, 93-109. https://doi.org/10.1016/j.ecolmodel.2016.12.018

GFCM, 2019. Working Group on Stock Assessment of Small Pelagic Species (WGSASP). Scientific Advisory Committee on Fisheries (SAC), FAO headquarters, Rome, Italy, 9-14 December 2019, p. 61.

Goñi, N., Arrizabalaga, H., 2010. Seasonal and interannual variability of fat content of juvenile albacore (Thunnus alalunga) and bluefin (Thunnus thynnus) tunas during their feeding migration to the Bay of Biscay. Progress in Oceanography 86, 115-123. https://doi.org/10.1016/j.pocean.2010.04.016

Guillén, J., Arin, L., Salat, J., Puig, P., Estrada, M., Palanques, A., Simarro, G., Pascual, J., 2019. Coastal oceanographic signatures of heat waves and extreme events of dense water formation during the period 2002-2012 (Barcelona, NW Mediterranean). Scientia Marina 82, 189-206.

Hartman, K.J., Brandt, S.B., 1995. Estimating energy density of fish. Transactions of the American Fisheries Society 124, 347-355.

Kent, M., 1990. Hand-held instrument for fat/water determination in whole fish. Food Control 1, 47-53. https://doi.org/10.1016/0956-7135(90)90121-R

Lambert, Y., Dutil, J.-D., 1997. Can simple condition indices be used to monitor and quantify seasonal changes in the energy reserves of cod (Gadus morhua)? Canadian Journal of Fisheries and Aquatic Sciences 54, 104-112.

Le Cren, E., 1951. The length-weight relationship and seasonal cycle in gonad weight and condition in the perch (Perca fluviatilis). The Journal of Animal Ecology 201-219.

Lloret, J., Faliex, E., Shulman, G.E., Raga, J.-A., Sasal, P., Muñoz, M., Casadevall, M., AhuirBaraja, A.E., Montero, F.E., Repullés-Albelda, A., 2012. Fish health and fisheries, implications for stock assessment and management: the Mediterranean example. Reviews in Fisheries Science 20, 165-180.

Lloret, J., Shulman, G., Love, R.M., 2014. Condition and Health Indicators of Exploited Marine Fishes. Wiley.

Mann, R.D., Peery, C.A., Pinson, A.M., Anderson, C.R., 2009. Energy use, migration times, and spawning success of adult spring-summer Chinook salmon returning to spawning areas in the South Fork Salmon River in Central Idaho.

Marin, M., Polak, T., Gašperlin, L., Žlender, B., 2010. Variations in the fatty acid composition and nutritional value of Adriatic sardine (Sardina pilchardus Walb.) through the fishing season. Acta Agriculturae Slovenica 96, 95-101.

Martín, P., Bahamon, N., Sabatés, A., Maynou, F., Sánchez, P., Demestre, M., 2008. European anchovy (Engraulis encrasicolus) landings and environmental conditions on the Catalan 
Coast (NW Mediterranean) during 2000-2005, in: Essential Fish Habitat Mapping in the Mediterranean. Springer, pp. 185-199.

Másílko, J., Zajíc, T., Hlaváč, D., Sampels, S., Mráz, J., Oberle, M., 2016. Rapid measurements of fat content in live and slaughtered common carp (Cyprinus carpio L.). Aquaculture International 24, 1669-1679. https://doi.org/10.1007/s10499-016-0058-1

McBride, R.S., Somarakis, S., Fitzhugh, G.R., Albert, A., Yaragina, N.A., Wuenschel, M.J., Alonso $\square$ Fernández, A., Basilone, G., 2015. Energy acquisition and allocation to egg production in relation to fish reproductive strategies. Fish and Fisheries 16, $23-57$.

McPherson, L.R., Slotte, A., Kvamme, C., Meier, S., Marshall, C.T., 2011. Inconsistencies in measurement of fish condition: a comparison of four indices of fat reserves for Atlantic herring (Clupea harengus). ICES Journal of Marine Science 68, 52-60.

Mesa, M.G., Rose, B.P., 2015. An assessment of morphometric indices, blood chemistry variables and an energy meter as indicators of the whole body lipid content in Micropterus dolomieu, Sander vitreus and Ictalurus punctatus. Journal of Fish Biology 86, 755-764. https://doi.org/10.1111/jfb.12600

Nikolsky, V., Shulman, G., Shchepkina, A., Yuneva, T., Bat, L., Kaya, Y., Kideyş, A., Seyhan, K., 2012. Assessment of food supply of small pelagic fish in the Black Sea based on their lipid content. Turkish Journal of Fisheries and Aquatic Sciences 12, 429-434.

Nunes, C., 2011. Integrating fish size, condition, and population demography in the estimation of Atlantic sardine annual fecundity. CiencMar 37, 565-584. https://doi.org/10.7773/cm.v37i4B.1779

Nunes, C., Silva, A., Soares, E., Ganias, K., 2011. The use of hepatic and somatic indices and histological information to characterize the reproductive dynamics of Atlantic sardine Sardina pilchardus from the Portuguese coast. Marine and Coastal Fisheries 3, 127-144.

Österblom, H., Olsson, O., Blenckner, T., Furness, R.W., 2008. Junk $\square$ food in marine ecosystems. Oikos 117, 967-977.

Palomera, I., Olivar, M.P., Salat, J., Sabatés, A., Coll, M., García, A., Morales-Nin, B., 2007. Small pelagic fish in the NW Mediterranean Sea: An ecological review. Progress in Oceanography 74, 377-396. https://doi.org/10.1016/j.pocean.2007.04.012

Parr Instrument Company, 2012. 1109A Semi-micro Oxygen Bombs Operating Instruction Manual. Parr Instrument Company. Moline, Illinois 61265-1770 USA.

Pecquerie, L., Petitgas, P., Kooijman, S.A.L.M., 2009. Modeling fish growth and reproduction in the context of the Dynamic Energy Budget theory to predict environmental impact on anchovy spawning duration. Journal of Sea Research 62, 93-105. https://doi.org/10.1016/j.seares.2009.06.002

Pedersen, J., Hislop, J.R.G., 2001. Seasonal variations in the energy density of fishes in the North Sea. Journal of Fish Biology 59, 380-389. https://doi.org/10.1111/j.10958649.2001.tb00137.x

Pennino, M.G., Bachiller, E., Lloret-Lloret, E., Albo-Puigserver, M., Esteban, A., Jadaud, A., Bellido, J.M., Coll, M., 2020a. Ingestion of microplastics and occurrence of parasite association in Mediterranean anchovy and sardine. Marine Pollution Bulletin 158, 111399.

Pennino, M.G., Coll, M., Albo Puigserver, M., Fernández Corredor, E., Steenbeek, J., Giráldez, A., González, M., Esteban, A., Bellido, J.M., 2020b. Current and future influence of environmental factors on small pelagic fish distributions in the Northwestern Mediterranean Sea.

Piroddi, C., Coll, M., Liquete, C., Macias, D., Greer, K., Buszowski, J., Steenbeek, J., Danovaro, R., Christensen, V., 2017. Historical changes of the Mediterranean Sea ecosystem: modelling the role and impact of primary productivity and fisheries changes over time. Scientific reports 7, 44491.

Piroddi, C., Coll, M., Steenbeek, J., Moy, D.M., Christensen, V., 2015. Modelling the Mediterranean marine ecosystem as a whole: addressing the challenge of complexity. Marine 
Ecology Progress Series 533, 47-65.

R Core Team, 2019. R: A language and environment for statistical computing. R Foundation for Statistical Computing, URL. Vienna, Austria.

Romero, E., Peters, F., Arin, L., Guillén, J., 2014. Decreased seasonality and high variability of coastal plankton dynamics in an urban location of the NW Mediterranean. Journal of Sea Research 88, 130-143. https://doi.org/10.1016/j.seares.2014.01.010

Rosa, R., Gonzalez L, Broitman BR, Garrido S, Santos AMP, Nunes ML, 2010. Bioenergetics of small pelagic fishes in upwelling systems: relationship between fish condition, coastal ecosystem dynamics and fisheries. Mar Ecol Prog Ser 410, 205-218.

Saraux, C., Van Beveren, E., Brosset, P., Queiros, Q., Bourdeix, J.-H., Dutto, G., Gasset, E., Jac, C., Bonhommeau, S., Fromentin, J.-M., 2019. Small pelagic fish dynamics: A review of mechanisms in the Gulf of Lions. Deep Sea Research Part II: Topical Studies in Oceanography 159, 52-61. https://doi.org/10.1016/j.dsr2.2018.02.010

Sardenne, F., Chassot, E., Fouché, E., Ménard, F., Lucas, V., Bodin, N., 2016. Are condition factors powerful proxies of energy content in wild tropical tunas? Ecological Indicators 71, 467-476. https://doi.org/10.1016/j.ecolind.2016.06.031

Schloesser, R.W., Fabrizio, M.C., 2017. Condition indices as surrogates of energy density and lipid content in juveniles of three fish species. Transactions of the American Fisheries Society 146, 1058-1069.

Schulte-Hostedde, A.I., Zinner, B., Millar, J.S., Hickling, G.J., 2005. Restitution of mass-size residuals: validating body condition indices. Ecology 86, 155-163.

Shulman, G.E., Love, R.M., 1999. The biochemical ecology of marine fishes. Academic Press.

Shulman, G.E., Nikolsky, V.N., Yuneva, T.V., Minyuk, G.S., Shchepkin, V.Y., Shchepkina, A.M., Ivleva, E.V., Yunev, O.A., Dobrovolov, I.S., Bingel, F., 2005. Fat content in Black Sea sprat as an indicator of fish food supply and ecosystem condition. Marine ecology progress series 293, 201-212.

Šimat, V., Bogdanović, T., 2012. Seasonal changes in proximate composition of anchovy (Engraulis encrasicolus, L.) from the central Adriatic 8.

Spitz, J., Mourocq, E., Schoen, V., Ridoux, V., 2010. Proximate composition and energy content of forage species from the Bay of Biscay: high- or low-quality food? ICES Journal of Marine Science 67, 909-915. https://doi.org/10.1093/icesjms/fsq008

Stevenson, R., Woods Jr, W.A., 2006. Condition indices for conservation: new uses for evolving tools. Integrative and comparative biology 46, 1169-1190.

Tirelli, V., Borme, D., Tulli, F., Cigar, M., Fonda Umani, S., Brandt, S., 2006. Energy density of anchovy Engraulis encrasicolus L. in the Adriatic Sea. Journal of Fish Biology 68, 982-989.

Tocher, D.R., 2003. Metabolism and functions of lipids and fatty acids in teleost fish. Reviews in fisheries science 11, 107-184.

Tufan, B., Koral, S., Köse, S., 2011. Changes during fishing season in the fat content and fatty acid profile of edible muscle, liver and gonads of anchovy (Engraulis encrasicolus) caught in the Turkish Black Sea. International Journal of Food Science \& Technology 46, 800-810. https://doi.org/10.1111/j.1365-2621.2011.02562.x

Van Beveren, E., Bonhommeau, S., Fromentin, J.-M., Bigot, J.-L., Bourdeix, J.-H., Brosset, P., Roos, D., Saraux, C., 2014. Rapid changes in growth, condition, size and age of small pelagic fish in the Mediterranean. Marine biology 161, 1809-1822.

Véron, M., Duhamel, E., Bertignac, M., Pawlowski, L., Huret, M., 2020. Major changes in sardine growth and body condition in the Bay of Biscay between 2003 and 2016: Temporal trends and drivers. Progress in Oceanography 182, 102274.

Wood, S.N., 2011. Fast stable restricted maximum likelihood and marginal likelihood estimation of semiparametric generalized linear models. Journal of the Royal Statistical Society: Series B (Statistical Methodology) 73, 3-36.

Wuenschel, M.J., Jugovich, A.R., Hare, J.A., 2006. Estimating the energy density of fish: the 
importance of ontogeny. Transactions of the American Fisheries Society 135, 379-385.

Zlatanos, S., Laskaridis, K., 2007. Seasonal variation in the fatty acid composition of three Mediterranean fish - sardine (Sardina pilchardus), anchovy (Engraulis encrasicholus) and

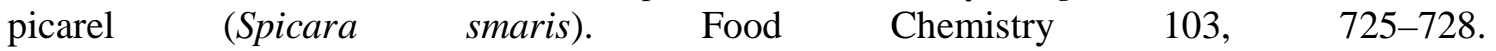
https://doi.org/10.1016/j.foodchem.2006.09.013 